B.A.J. 7, IV, 513-518 (2001)

GUEST EDITORIAL

\title{
CLOAKS WITHOUT DAGGERS
}

\author{
By B. J. Riley
}

It was a kind of secret service. Over a great many years, first in life assurance, and then in occupational pensions, the actuarial profession lived largely in world of its own. It was protected by specialist legislation, and, to a great extent, it devised its own rules. In those circumstances the cloak of obscurity and the use of almost indecipherable codes seemed completely appropriate. The only obvious penalty was the stream of jokes about remoteness and mumbo-jumbo. But, quite suddenly, the environment has changed drastically. The profession faces overwhelming calls for greater transparency.

Opacity has some obvious, if perhaps sometimes rather dangerous, attractions. It allows flexibility, in that reserves can be set up and benefits can be shifted judgementally, not to say arbitrarily, between different members or investors. Awkward surpluses or deficits can be cut down to size through quite small adjustments to the assumptions about future investment returns or growth in liabilities. In particular, the with-profits approach smoothed out investment returns and encouraged investors to accept investment risks which otherwise they would not have done. From the 1950s onwards, the rise and rise of the equity market gave the actuarial profession a marvellous opportunity to develop high-return products which appeared not to involve substantial risks.

There are also, however, obvious drawbacks to lack of transparency. It opens the way for unfairness, which will not easily be understood, or forgiven, by outsiders when they find out what is going on. Although the actuaries themselves these days talk about 'asset shares', the presentation to investors is still misleadingly couched in terms of 'bonuses' rather than rightful entitlements. The arbitrary, and usually cruel, treatment handed out to investors who cannot, or will not, fulfil a 25 -year contract, has caused regular dissent over the years. The Government had to take action in the 1980 s to protect the occupational pension rights of 'early leavers' (actually, simply job-changers); at the time, meanness to job-shifters cut the cost of defined benefit schemes by about half.

If the public becomes suspicious, decades of painfully-built confidence may be destroyed. Outsiders may conclude that the lack of transparency provides an opportunity for covering up mistakes; after all, the scandal of orphan estates has been simmering for decades, and a line has still not been drawn under the lingering unattributed hoards at several leading life offices. 
An important factor is that opacity sits uncomfortably with competition. By the 1970s and 1980s life and pensions business was becoming very competitive, and, in particular, it was driven by performance league tables. The scope for manipulating the numbers which appeared in such tables was considerable, especially because small numbers of maturing policies could dominate the figures, even for quite large offices. This placed increasing pressure on the actuaries who calculated with-profits bonuses, and on the Appointed Actuaries with the responsibility of protecting solvency. As competition intensified, it sometimes appeared that bonuses were driving solvency, instead of the other way round. Equitable Life has, in the past couple of years, provided the biggest headlines; but there has been a string of cases since the 1980s, going back to the example of U.K. Provident, in which overstretched life offices have had to be bailed out, or have quietly downgraded their with-profits investment strategies in order to avoid breaching solvency rules.

It was inevitable that the great boom in life and pensions business would last only as long as the inexplicably extended bull market in equities. Through the 1980s and 1990s equity returns averaged between 15 and 20 per cent a year. Total returns on gilt-edged were not much less (though falling gilt yields carried a vicious sting in the tail, to Equitable's cost). Actuaries knew that the returns were not sustainable in the long run, but year after year the party continued, and it was the cautious actuaries that were proved wrong, not the aggressive ones - until, that is, the bubble finally burst at the end of 1999.

Actuaries are under acute pressure simultaneously in several product areas. The with-profits formula has, of course, come under great pressure: at Equitable Life it was especially ill-designed, being inadequately backed by contingency reserves, and there have been widespread problems at many other offices with endowment mortgages, where customers often did not understand the risks. Under cover provided by inadequate disclosure conventions, the traditional endowment policy was replaced during the 1980s by an inferior 'low cost' version.

There are also serious pressures in occupational pensions, where the great 20 -year bull market in equities covered up a great many cracks. Now the bear market is opening them wide. In 1997 Gordon Brown, the Chancellor of the Exchequer, effectively destroyed a marvellous cloaking device, the actuarial valuation based on dividend income, when he removed pension funds' tax relief on United Kingdom dividends. The accountancy profession has seized its opportunity to come along with FRS 17, the new accounting standard for pension costs, shifting the emphasis drastically from smoothed actuarial valuations, which were recognised in the previous standard SSAP 24, to volatile market prices.

This is said by the auditors to be an example of fair value accounting, and it has obvious attractions. It offers short-term accuracy, of a kind, and 
superficial fairness. Values are set externally rather than internally. However, the assumption that market values represent any kind of reliable 'truth' is highly debatable. They may provide the only practical route for the valuation of long-term contracts at any point in time. But, in the aftermath of a remarkable bubble in the global stock markets - especially in the technology-related sectors - and a subsequent brutal correction, it is hard to argue that market values are necessarily soundly-based in terms of fundamentals. At best, they fluctuate erratically around a hazily-defined fair value level.

True, over the years academics have attempted to elevate the securities markets' price-setting process into a reliable encapsulation of all known information about companies. The efficient markets hypothesis has been combined with rational expectations theories to formulate a structure of fundamental value formulation. But too many companies have joined the ' 90 per cent' club of major stock market victims during the past two years or so to render the stock market's processes very credible. It appears that momentum investors have crowded out the more traditional value investors. True, in 1999 and early 2000 the circumstances were extreme; normally the markets perform a more accurate job, but that does not make market prices reliable benchmarks in the short term for valuing long-term contracts.

For 90 or 95 per cent of the time the markets behave efficiently. But that leaves unanswered the problem of market stress. Long-term models must be robust against the kinds of emergencies that happen only once or twice a century. The big danger is that rules based inflexibly on market prices will lead to forced selling at the bottom of the cycle. It happened quite dramatically, for instance, when Burmah Oil breached its banking covenants at the end of 1974, because the share price of British Petroleum dived temporarily. That was a flaw in banking practices; similar stresses hit life companies and pension funds at the same period, but actuarial valuation models were flexible enough at the time for the problems, in the vast majority of cases, to be rolled over until financial conditions improved.

Finance directors are now pondering the potential risks of FRS 17. 'Mark to market' is a well-tested principle in the banking sector, but it requires much tighter risk control procedures than are practised in pension funds. The accounting standard exposes companies to the volatility experienced at stock market extremes; true, these risks can be hedged by shifting pension fund investment strategy towards heavy allocations to corporate bonds, but that would reduce prospective investment returns and raise the probable level of scheme costs.

What will happen in extreme circumstances? The nightmare of forced selling at the bottom of the market, or the shotgun addition of new funds in order to comply with inflexible solvency rules, has to be reckoned with. More likely, sponsoring companies will simply back away from the risk of being forced to inject new capital in the middle of a financial crisis. True, the 
bottom of a bear market should turn out to be a good time to buy equities, but that is of little merit to sponsors themselves faced with financial ruin.

So, finance directors are worried, but so should individual investors be. Transparency serves to transmit market volatility into the benefit packages to which individuals subscribe. Under the traditional approach, the investor never really knew what the outcome would be until the terminal bonus was declared and the cheque arrived. For decades, moreover, good fortune lent a hand; the great bull market reduced the possibility of serious disappointment. Now, in endowment mortgages the more transparent approach requires constant recalculation, and customers are perversely invited to subscribe more money into policies that have been performing badly. Does transparency mean throwing good money after bad?

What is at stake here is the underlying transfer, which we have seen proceeding for many decades, of actuarial activity from the fixed income markets into equities. We may be about to see a retreat into bonds. The original transformation was spearheaded by George Ross Goobey in the late 1940s, against strong opposition from the actuarial profession at the time. At that period high quality U.K. equities yielded more than gilts, and offered much better fundamental value, because memories of the 1930s were still misleadingly fresh; low, or negative, inflation and weak and volatile economic growth were assumed quite probable, but this turned out to be a very inaccurate representation of the post-war world.

Most leading actuaries of the day were committed to gilts, even though Hugh Dalton had been trying to push long gilt-edged yields down to $2 \frac{1}{2}$ per cent (even more niggardly than the $4 \frac{1}{2}$ per cent achieved in the modern era by Gordon Brown). But it was very helpful to the proponents of equities that the reliability (and indeed strong growth) of dividends, at least in the aggregate, made it straightforward to fit equities into the traditional incomebased methodology of the actuarial profession. What followed was a period of several decades in which strong momentum effects pushed equities higher and higher. As money from pension funds and with-profits funds poured into the stock market, the indices became locked into a strong upwards trend, which reached its most reliable period during the 1980s and 1990s. By the late 1990s many actuaries became doubtful that the trend could last much longer, and pessimistic actuarial papers were written about the equity risk premium. However, it is almost impossible to argue against a trend which has lasted 20 years. With-profits and pension funds, in many cases, continued to have exposures of up to 80 per cent to equities.

In the end, however, Gordon Brown launched a deadly assault on the actuaries' dividend discount model in 1997. The Labour Government's argument was that the payment of high dividend levels amounted to a waste of British companies' resources, which should be invested directly in the expansion of productive capacity, and therefore in more rapid growth. This argument did not make much sense, because dividends paid to pension funds 
are recycled into the market, where they are allocated to the most attractive opportunities. Anyway, there was little evidence that U.K. companies were short of capital to exploit attractive investment projects.

The pensions industry protested, but not too loudly, for fear of undermining what had turned out to be a highly profitable model for asset managers and consultants. Even if Gordon Brown had not struck, it is likely that the increasing globalisation of the equity market would have made it impractical for U.K. companies to continue to pursue a much more dividendintensive financial model than was common in other countries (especially the United States of America). Anyway, the stock market perversely continued to rise for more than another two years, but the basis for a fundamental retreat into bonds had been established.

The logic of tax discrimination against dividends (and continuing tax relief on bond coupons) is that the risk structure of corporate finances is changing. Equities have become less well supported by a high and rising income for investors, and have therefore become more volatile in price. Income-seeking investors are being drawn into corporate bonds, a sector of the capital market that shrivelled almost to nothing during the great dividend-driven equity bull market of the 1980s and 1990s. As corporate bond issuance expands, the gearing of British companies will increase, both in terms of capital and income. Equity capital will be pushed towards the edge; shares will become more speculative, almost option-like.

All this provides the background for the pressures which are being faced by the actuarial profession. A steady, smoothed model for valuing equities has become impractical. In the occupational pensions industry, an alternative model was sought during the negotiations between accountants and actuaries which led up to FRS 17, but one was not produced. Actuaries are being pushed towards market-based valuations, and greater transparency.

The way ahead is itself far from being transparent. The best that can be said is that the damage done by the recent equity bear market may usher in an era of more modest expectations on the part of long-term investors. The risks of technology funds, for instance, have become widely appreciated. It may then be possible for the actuarial profession to develop long-term valuation techniques which look through irrational market pricing and fasten onto fundamental values. Whether actuary-designed contracts of this kind could cope with future bull and bear markets is doubtful, however; customers would need to be locked in, and huge reserves accumulated, the sorts of problems that have already caused great difficulties.

Actuaries have been successful in the past when they have devised opaque products which have suppressed the natural risk-aversion of many investors, thus opening the way for higher investment returns. They have also relied on the generation of surpluses, whether because of falling long-term bond yields or rising equity prices, events which have not been anticipated, or fully understood in terms of attributable asset shares, by customers. 
There is, moreover, the challenge of tighter regulation. The Equitable Life crisis has left the Financial Services Authority bruised, and saying: "never again". Its future safeguards will include more transparency and a greater reliance on regulation by rigid formula. The flexibility which was a great, and largely hidden, asset of the actuarial tradition will become even less useful.

Curiously, the real secret service has also emerged from the shadows. Its building is perched ostentatiously on the bank of the River Thames, and the ex-chief of MI5, Stella Rimington, has published her autobiography. With the end of the Cold War the spooks appeared to face an uncertain future, but now new opportunities are springing up in all sorts of unexpected places.

The actuarial profession, blinking in the unaccustomed glare of publicity, has become a victim of the equity bear market. Things will never be quite the same again, but new opportunities will arise, probably out of unexpected problems. The profession is searching for cloaks that need not involve the use of daggers.

Barry Riley is Investment Editor of the Financial Times, and an Honorary Fellow of the Institute of Actuaries. 